\title{
PENGEMBANGAN LEMBAR KERJA SISWA DENGAN PENDEKATAN KERJA LABORATORIUM UNTUK MENINGKATKAN KETERAMPILAN PROSES FISIKA
}

\author{
Sulistiyono $^{1}$, Mundilarto ${ }^{2}$, Heru Kuswanto ${ }^{3}$ \\ Program Studi Pendidikan Fisika, STKIP PGRI Lubuklinggau ${ }^{1}$ \\ Program Studi Ilmu Pendidikan, Program Pascasarjana Universitas Negeri Yogyakarta ${ }^{2,3}$ \\ sulistiyono@gmail.com ${ }^{1}$
}

Submit, 21-12-2017 Accepted, 29-12-2017 Publish, 29-12-2017

\begin{abstract}
Student Worksheet (LKS) that is in suitable with the characteristics of laboratory work approach. This research also aims to cultivate the physics process skill of the students during the teaching of laboratory work. This is a Research and Development $(R \& D)$ developed by Borg \& Gall. The stages in this research are collecting information, making plan, developing initial product, conducting tryout, doing revision of the product. The initial tryout or limited tryout is done to grade XI SMAN margabaru. The instrument is Lesson Plan (RPP), Student Worksheet (LKS) validation sheet, physics process skill observation sheet, students' response questionnaire. Data analysis is descriptive qualitative.The result shows that LKS developed based on expert validation test on the aspect of writing approach, the depth of physics concept, scoring aspects, student activity and physical appearance is in the criteria of very good. For LKS identity completeness, clarity of sentence and language is in the criteria of good. Meanwhile, the percentage of the physics process skill achievement as compiling the hypothesis, skill of identifying variables, skill of filling the tables, skill of making graphs, skill of investigation analysis and the skill of drawing conclusion, is 92\%, 93\%, 80\%, 90\%, 78\%, dan $78 \%$.
\end{abstract}

Keywords: Student Worksheet (LKS), laboratoey work, physics process skill

\begin{abstract}
Abstrak:Penelitian ini bertujuan untuk menghasilkan Lembar Kerja Siswa (LKS) yang sesuai dengan karakteristik pendekatan kerja laboratorium. Selain itu, penelitian juga bertujuan untuk menumbuhkan keterampilan proses fisika siswa selama mengikuti pembelajaran kerjalaboratorium. Jenis penelitianini adalah Research and Development $(R \& D)$ yang dikembangkan oleh Borg \& Gall. Tahap-tahap pada penelitian ini adalah melakukan pengumpulan informasi, melakukan perencanaan, mengembangkan bentuk produk awal, melakukan uji coba lapangan pendahuluan, melakukan revisi terhadap produk utama. Uji coba pendahuluan atau uji coba terbatas dilakukan di kelas XI SMAN margabaru. Instrumen yang digunakan dalam penelitian ini adalah RPP, lembarvalidasi LKS, lembar observas iketerampilan proses fisika, dan angket respon siswa. Pengolahan data dalam penelitian ini dilakukan secara deskriptif kualitatif. Hasil penelitian menunjukkan bahwa LKS yang dikembangkan berdasarkan uji validasi ahli pada aspek pendekatan penulisan, kedalaman konsep fisika, aspek penilaian, kegiatan siswa, dan penampilan fisik masing-masing berada dalam kriteria sangat baik. Untuk aspek kelengkapan identitas LKS, kejelasan kalimat dan kebahasaan berkriteria baik.Sedangkan persentase ketercapaian keterampilan proses fisika berupa menyusun hipotesis, keterampilan mengidentifikasi variabel, keterampilan mengisitabel, keterampilan membuat grafik, keterampilan analisis investigasi, dan keterampilan menarik kesimpulan masing-masing sebesar 92\%, 93\%, 80\%, 90\%, 78\%, dan 78\%.
\end{abstract}

KataKunci: LKS, kerja laboratorium, keterampilan proses fisika

\section{PENDAHULUAN}

Implementasi Kurikulum 2013 adalah kurikulum yang dirancang baik dalam bentuk dokumen, proses, maupun penilaian didasarkan pada pencapaian tujuan, konten dan bahan pelajaran serta penyelengaraan pembelajaran yang didasarkan pada standar kompetensi lulusan. Kurikulum ini menekankan kepada pemahaman tentang apa dialami siswa akan menjadi hasil belajar pada dirinya dan menjadi hasil kurikulum, sehingga proses pembelajaran seharusnya memberikan kesempatan yang luas kepada siswa untuk mengembangkan 
potensi dirinya. Kurikulum 2013 bertujuan untuk mengarahkan siswa menjadi manusia berkualitas yang mampu dan proaktif menjawab tantangan zaman yang selalu berubah, menjadi manusia terdidik yang beriman dan bertakwa kepada Tuhan Yang Maha Esa, beraklah mulia, sehat, berilmu, cakap, kreatif, mandiri, serta menjadi warga negara yang demokratis dan bertanggung jawab.

Guru memiliki peran penting dalam proses implementasi Kurikulum 2013, karena gurulah yang menjalankan kegiatan belajar mengajar. Seperti pernyataan Lauridsen (2013), "Teachers are the actual delivers of curriculum across disiplines and acress grade levels" Guru merupakan pengantar kurikulum yang sesungguhnya pada berbagai bidang ilmu dan padaberbagai tingkat kelas, sehingga guru menjadi ujung tombak utama imlementasi Kurikulum 2013.

Kesiapan guru dalam melaksanakan Kurikulum 2013 akan berpengaruh terhadapproses pembelajaran dan hasil ahir pembelajaran di sekolah. Kesiapan guru pun lebih penting daripada pengembangan kurikulum 2013 karena guru merupakan garda terdepan dalam melaksanakan kurikulum. Guru bukan saja hanya menguasai apa yang diajarkan, tetapi juga harus menguasai bagaimana pembelajaran peserta didik yang menantang, menyenangkan, memotivasi, mengispirasi, dan memberi ruang kepada peserta didik untuk melakukan keterampilan proses.

Keterampilan proses adalah keterampilan fisik dan mental terkait dengan kemampuan-kemampuan mendasar yang dimiliki, dikuasai dan diaplikasikan dalam suatu kegiatan ilmiah sehingga para ilmuan berhasil menemukan sesuatu yang baru (Semiawan,2011). Keterampilan proses melibatkan keterampilan-keterampilan kognitif atau intelektual, manual dan sosial. Keterampilan intelektual memicu siswa menggunakan pikirannya.
Keterampilan manual melibatkan siswa dalam menggunakan alat dan bahan, mengukur, menyusun atau merakit alat (Collete, 2010).

Proses sains diturunkan dari langkah-langkah yang dikerjakan saintis ketika melakukan penelitian ilmiah. Langkah-langkah tersebut merupakan keterampilan proses sains. Mundilarto (2010) menyebutkan bahwa keterampilan proses sains mencakup: observasi, mengukur, inferensi, memanipulasi variabel, merumuskan hipotesis, menyusun grafik dan tabel data, mendefinisikan variabel secara operasional, dan melaksanakan eksperimen. Pendekatan proses dapat memberikan pemahaman yang benar tentang hakikat sains. Dengan demikian, siswa dapat mengalami excitement sains dan dapat memahaminya dengan lebih baik.

Menurut Depdiknas (2005) lembar kegiatan siswa (student worksheet) adalah lembaran-lembaran yang berisi tugas yang biasanya berupa petunjuk atau langkahlangkah untuk menyelesaikan tugas yang harus dikerjakan siswa. Tugas-tugas dalam LKS dapat berupa teori atau tugastugas praktis (kerja laboratorium atau kerja lapangan). Lebih lanjut Hendro Darmodjo dan Jenny R. E. Kaligis (1993) mengemukakan bahwa salah satu sarana yang digunakan untuk mengoptimalkan keterlibatan atau aktivitas siswa dalam pembelajaran adalah dengan penggunaan lembar kegiatan siswa (LKS).

LKS tersebut berisi rangkuman materi pelajaran disertai dengan kumpulan soal serta sedikit kegiatan praktikum yang bertujuan untuk membuktikan rumus fisika yang telah diberikan, namun kegiatan praktikum ini jarang dilakukan dan kurang mengeksplor keterampilan proses fisika siswa. Dalam LKS tersebut, kegiatan praktikum dan teori atau konsep fisika diajarkan secara terpisah. Sehinggabanyak siswa yang kuat dikonsep namun lemah pada prakteknya. 
Berdasarkan masalah tersebut peneliti bermaksud membuat perangkat pembelajaran berupa LKS dengan pendekatan kerja laboratorium untuk menumbuhkan keterampilan proses fisika siswa. LKS yang dikembangkan diharapkan mampu membuat siswa aktif, mampu membuat siswa menemukan sendiri konsep fisika, mampu mengintegrasikan teori dan konsep fisika secara bersamaan, dan mampu mengeksplor keterampilan proses fisika siswa.

\section{METODE PENELITIAN}

Penelitian ini menggunakan rancangan dan pendekatan penelitian pengembangan (research and Develop / $R$ $\& D)$ atau termasuk dalam penelitian pengembangan.Borg \& Gall (2003) menyatakan bahwa penelitian dan pengembangan pendidikan pada dasarnya merupakan proses yang digunakan untuk mengembangkan dan memvalidasi produk-produk pendidikan. Tahapan peneltian pengembangan meliputi: Melakukan pengumpulan informasi awal; Melakukan perencanaan; Mengembangkan produk awal; Melakukan uji coba; Melakukan revisi terhadap produk utama. Penelitian dilakukan pada sampel 34siswa.

Dalam penelitian ini teknik analisis data yang dilakukan diantaranya:

1. Uji validitas

a. Melakukan tabulasi semua skor yang diperoleh setiap aspek penilaian

b. Menghitung skor rata-rata dari setiap aspek dengan menggunakan rumus:

$$
\begin{aligned}
& X=\frac{\sum x}{N} \\
& \text { Keterangan: } \\
& X=\text { skor rata-rata } \\
& \sum x=\text { total skor tiap komponen } \\
& \quad \text { penilaian } X \\
& N=\text { jumlah penilai }
\end{aligned}
$$

c. Mengubah skor rerata dari setiap komponen penilai menjadi nilai kualitatif berdasarkan kriteria penilaian

Tabel 1. Kriteria Penilaian

\begin{tabular}{lll}
\hline No & \multicolumn{1}{c}{ Rentang Skor $(i)$} & $\begin{array}{c}\text { Kategori } \\
\text { kualitas }\end{array}$ \\
\hline $\mathbf{1}$ & $\mathrm{M}_{\mathrm{i}}+1,8 \mathrm{SD}_{\mathrm{i}}<\mathrm{X}$ & Sangat Baik \\
$\mathbf{2}$ & $\mathrm{M}_{\mathrm{i}}+0,6 \mathrm{SD}_{\mathrm{i}}<\mathrm{X} \leq \mathrm{M}_{\mathrm{i}}+1,8 \mathrm{SD}_{\mathrm{i}}$ & Baik \\
$\mathbf{3}$ & $\mathrm{M}_{\mathrm{i}}-0,6 \mathrm{SD}_{\mathrm{i}}<\mathrm{X} \leq \mathrm{M}_{\mathrm{i}}+0,6 \mathrm{SD}_{\mathrm{i}}$ & Cukup \\
$\mathbf{4}$ & $\mathrm{M}_{\mathrm{i}}-1,8 \mathrm{SD}_{\mathrm{i}}<\mathrm{X} \leq \mathrm{M}_{\mathrm{i}}-0,6 \mathrm{SD}_{\mathrm{i}}$ & Kurang \\
$\mathbf{5}$ & $\mathrm{X} \leq \mathrm{M}_{\mathrm{i}}-1,8 \mathrm{SD}_{\mathrm{i}}$ & Sangat \\
& & Kurang \\
\hline
\end{tabular}

Dengan:

$\mathrm{SD}_{\mathrm{i}}$ : standar deviasi ideal

$\mathrm{M}_{\mathrm{i}} \quad$ : mean ideal

2. Analisis reliabilitas instrument dengan persamaan percentage agreement $(R)$

$(R)=100 \%\left(1-\frac{\mathrm{A}-\mathrm{B}}{\mathrm{A}+\mathrm{B}}\right)$

Keterangan

A: SkorTertinggi

B: SkorTerendah

3. Analisisujicobaprodukdenganmengana lisisketercapaianketerampilan proses siswayang dilihat dari rata-rata skor akumulasi (skor akhir) yang diperoleh siswa. Pada setiap komponen penilaian, data dianalisis menggunakan presentase ketercapaian sebagai berikut:

Ketercapaian $=\frac{\text { jumlah skor }}{\text { skor } \text { maksimal }} \times 100 \%$ (2)

4. Analisis respon siswa dianalisis seperti langkah menganalisis uji validasi

\section{HASIL DAN PEMBAHASAN Hasil Penelitian}

Data yang diperolah dalam penelitian pengembangan ini adalah LKS dengan pendekatan laboratorium, berdasarkan data hasil evaluasi produk pada aspek pendekatan penulisan Rata-rata skor pada aspek ini adalah 13. Skor ini menunjukkan bahwa validator menyatakan LKS berorientasi pada kerja laboratorium berkualitas sangat baik. LKS yang dikembangkan dapat mengajak siswa aktif dalam pembelajaran, dapat menghubungkan ilmu pengetahuan dan 
teknologi dengan kehidupan sehari-hari, dan langkah kerja pada LKS sesuai untuk mengembangkan keterampilan proses fisika siswa. Kemudian kedalaman konsep fisikaRata-rata skor pada aspek ini adalah 14. Skor ini menunjukkan bahwa validator menyatakan LKS berorientasi pada kerja laboratorium berkualitas sangat baik. Bahwa materi dalam LKS yang dikembangkan sesuai dengan SK-KD kurikulum 2013 SMA dan pemilihan alat yang digunakan dalam setiap kegiatan sesuai dengan materi pembelajaran.

Selanjutnya untuk aspek penilaian, Rata-rata skor pada aspek ini adalah 4.5. Skor ini menunjukkan bahwa validator menyatakan LKS berorientasi pada kerja laboratorium berkualitas sangat baik. LKS yang dikembangkan dapat mengukur keterampilan proses siswa berupa menyusun hipotesis, mengidentifikasi variabel, tabulasi data, membuat grafik, analisis investigasi, dan menarik kesimpulan. Untuk aspek kegiatan siswa (kerja laboratorium), Rata-rata skor pada aspek ini adalah 13.5. Skor ini menunjukkan bahwa validator menyatakan LKS berorientasi pada kerja laboratorium berkualitas sangat baik. LKS yang dikembangkan dapat memberikan pengalaman langsung bagi siswa, dapat menuntun siswa dalam menyimpulkan konsep, hukum atau fakta, dan kerja laboratorium yang direncanakan sesuai dengan materi pelajaran. Dan yang terahir adalah, penampilan fisik LKS rata-rata skor pada aspek ini adalah 13. Skor ini menunjukkan bahwa validator menyatakan LKS berorientasi pada kerja laboratorium berkualitas sangat baik. Desain, tulisan dan gambar dalam LKS yang dikembangkan dapat mendorong minat belajar baca.

\section{Pembahasan}

Penelitian ini bertujuan untuk menghasilkan produk LKS yang sesuai dengan karakteristik pendekatan kerja laboratorium, kemudian untuk mengetahui ketercapaian keterampilan proses fisika siswa selama mengikuti pembelajaran dengan menggunakan LKS yang telah dikembangkan. Uji coba produk LKS dilaksanakan dengan maksud untuk mengukur keterampilan proses fisika awal siswa. Keterampilan proses yang diamati merupakan keterampilan terpadu proses sains yang diadaptasi Zuhdan (2012), yang meliputi keterampilan menyusun hipotesis, mengidentifikasi variabel, membuat tabel, membuat grafik, analisis investigasi, dan menarik kesimpulan.

Data ketercapaian keterampilan proses fisika siswa menggunakan LKS yang dikembangkan adalah sebagai berikut:

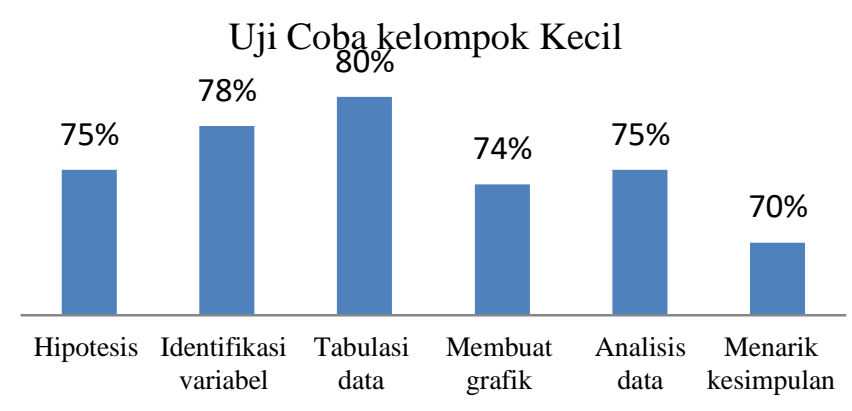

Gambar 1. Uji coba kelompok kecil

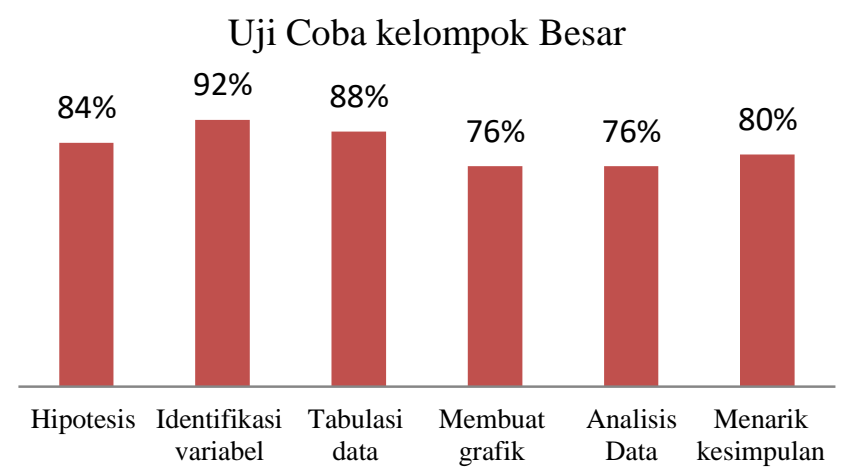

Gambar 2. Uji coba kelompok besar

Peningkatan

ketercapaian

keterampilan proses fisika tersebut membuktikan bahwa LKS berorientasi pada kerja laboratorium dapat meningkatkan keterampilan proses fisika siswa.

Berdasarkan hasil keterampilan proses fisika siswa, ini membuktikan bahwa LKS yang peneliti kembangkan 
dapat digunakan untuk meningkatkan keterampilan proses fisika, khususnya keterampilan menyusun hipotesis, mengidentifikasi variabel, tabulasi data, membuat grafik, analisis investigasi dan menarik kesimpulan. Namun LKS ini belum sempurna, karena masih ada siswa yang mengeluhkan tentang LKS berorientasi pada kerja laboratorium yang peneliti kembangkan.

LKS berorientasi pada kerja laboratorium berkualitas sangat baik. Berdasarkan hasil angket respon siswa mayoritas siswa setuju bahwa LKS yang dikembangkan dapat membatu dalam belajar aktif dan membantu menghubungkan ilmu pengetahuan dan teknologi dengan kehidupan sehari-hari. LKS yang dikembangkan dapat membantu memahami konsep fisika, membantu melakukan prosedur eksperimen, memudahkan mengamati gejala fisika dalam ekperimen, dan dapat membantu memberi pengalaman langsung dalam pelaksanaan proses belajar mengajar serta mampu mengembangkan keterampilan proses fisika siswa.

Pengembangan LKS dengan pendekatan kerja laboratorium sebagai metode pembelajaran aktif yang mengharuskan siswa untuk terlibat dalam mengamati atau memanipulasi benda nyata dan bahan, memiliki peran khusus dan pusat untuk pengembangan pemahaman siswa tentang konsep-konsep ilmiah, meningkatkan keterampilan kognitif serta mengembangkan sikap positif Brown et al, Holmes \& Wieman (2016). Kerja laboratorium dapat member siswa kesempatan untuk terlibat dalam praktik ilmiah otentik, mengembangkan teknis, keterampilan laboratorium, dan terlibat secara kolaboratif dengan lainnya dalam merancang dan membangun eksperimen, mengumpulkan dan menafsirkan data, dan mengkomunikasikan konten ilmiah, Wilcox\& Lewandowski (2016a, 2016b).

\section{SIMPULAN}

Berdasarkan hasil analisis data dan pembahasan yang telah dilakukan dapat disimpulkan:

1. Kualitas Lembar Kerja Siswa (LKS) dengan pendekatan kerja laboratorium secara keseluruhan berkualitas "baik" dan layak digunakan dalam pembelajaran.

2. Dampak penerapan Lembar Kerja Siswa (LKS) dengan pendekatan kerja laboratorium dalam pembelajaran fisika adalah keterampilan proses siswa yang semakin bagus tiap-tiap indikator mulai dari menyusun hipotesis, mengidentifikasi variabel, mengisi tabel, membuat grafik, analisis investigasi dan menarik kesimpulan.

3. Berdasarkan hasil respon siswa terhadap Lembar Kerja Siswa (LKS) dengan pendekatan kerja laboratoriumyang telah digunakan dalam pembelajaran, termasuk dalam kategori "baik".

\section{DAFTAR PUSTAKA}

Borg, W.R. \& Gall, M.D. (2003). Educational research: an introduction. $4^{\text {th }}$ Edition. New York: Longman Inc.

Collete, Alfred T. \& Chiappetta, Eugene L. (2010). Science instruction in the middle and secondary school. New York: Macmillan Publishing Company.

Depdiknas. (2005). Pedoman penyusunan LKS SMA (versi elektronik). Jakarta: Depdiknas.

Hendro, Darmodjo \& Kaligis, Jenny R.E. (1993). Pendidikan IPA II. Jakarta: Dirjen Dikti.

Holmes, NG \& Wieman, CE.(2016). Examining and contrasting the cognitive activities engaged in undergraduate research experiences and lab courses. 
Physical Review Physics

Education Research. 12, 020103

Laudirsen, D. A. (2013). What are teachers' perceptionof the curriculum development process. The Ohio State University. Diambil Pada Tanggal 15 November 2017, dari: https://etd.ohiolink.edu/ap/10.

Mundilarto. (2010). Kapita Selekta Pendidikan Fisika. Yogyakarta: UNY Press.

Semiawan, (2011). Pendekatan Keterampilan Proses, Bagaimana Mengaktifkan Siswa dalam Belajar. Jakarta: PT. Grasindo.

Wilcox, B.R \& Lewandowski, H.J. (2016b). Developing Skills Versus Reinforcing Concepts In Physics Labs: Insight From a Survey Of Students' Beliefs About Experimental Physics. Physical Review Physics Education Research 13, 010108,1-9.

Zuhdan K. Prasetyo, (2012). Kapita Selekta Pembelajaan Fisika. Jakarta: Universitas Terbuka 